\title{
Rekrutmen Tenaga Pendidik di SMA
}

\author{
Qurratu A'yun ${ }^{1}$, Ali Imron ${ }^{1}$, Imron Arifin ${ }^{1}$ \\ ${ }^{1}$ Manajemen Pendidikan-Universitas Negeri Malang
}

\begin{tabular}{l}
\hline INFO ARTIKEL \\
\hline Riwayat Artikel: \\
Diterima: 08-04-2019 \\
Disetujui: 16-07-2019 \\
\hline
\end{tabular}

\author{
Kata kunci: \\ recruitment of teaching staff; \\ management; \\ human resources; \\ rekrutmen tenaga pendidik; \\ manajemen; \\ sumber daya manusia
}

\author{
Alamat Korespondensi: \\ Qurratu A'yun \\ Manajemen Pendidikan \\ Universitas Negri Malang \\ Jalan Semarang 5 Malang \\ E-mail: qurratuayaun126@gmail.com
}

\begin{abstract}
ABSTRAK
Abstract: This study aims to determine the' recruitment process of teacher in Darul Ulum 2 Jombang High School because the quality of the teacher depends on the recruitment and selection procedures carried out by the committee. This research method was qualitative research, while data collection used interviews, and document studies. The results'show that the implementation of recruitment aims to get professional educators. Before carrying out recruitment, it is necessary to prepare the recruitment process. Preparation and recruitment process must be completely well-planned so that the recruitment obtain good teachers since it impacts on student output.

Abstrak: Penelitian ini bertujuan untuk mengetahui proses rekrutmen guru di SMA 2 Darul Ulum Jombang dikarenakan kualitas tenaga pendidik di sekolah sangat bergantung pada prosedur rekrutmen dan seleksi yang dilaksanakan oleh panitia. Metode penelitian ini menggunakan penelitian kualitatif. Adapun pengumpulan data menggunakan wawancara mendalam, observasi, dan studi dokumentasi. Hasil dari penelitian ini merupakan implementasi rekrutmen tenaga pendidik bertujuan untuk mendapatkan tenaga pendidik yang profesional dan memiliki kualifikasi yang terbaik. Sebelum melakukan kegiatan perekrutan diperlukan persiapan dan proses yang matang. Persiapan dan perekrutan tenaga pendidik ini harus benar-benar "matang" sehingga melalui rekrutmen tersebut sekolah dapat memperoleh tenaga pendidik yang profesional sesuai dengan kriteria sekolah kerena akan berdampak pada output siswa."
\end{abstract}

Sumber Daya Manusia adalah proses yang menanggani suatu masalah dalam ruang lingkup pegawai, karyawan, manajer, buruh dan tenaga kerja serta staf lainnya sebagai penunjang suatu aktivitas dalam organisasi atau lembaga untuk mencapai suatu tujuan yang telah ditentukan dalam manajerial. Pengurus SD bagian atau unit yang biasanya bekerja dalam SDM merupakan departemen SDM (human resource department). (Listanti \& Nurhikmahyanti, 2014) salah satu kunci utama dalam menciptakan SDM tenaga pendidik yang baik dan berkualitas adalah terletak pada proses rekrutmen karena proses tersebut terjadi seleksi calon tenaga pendidik. Manajemen Sumber Daya Manusia (MSDM) adalah ilmu dan seni yang mengatur peranan tenaga pendidik secara efisien sehingga tercapai tujuan bersama lembaga, karyawan, dan masyarakat.

Dengan adanya perubahan teknologi yang sangat pesat, memaksa tenaga pendidik untuk menyesuaikan diri dengan lingkungannya. Perubahan tersebut telah menggeser fungsi-fungsi MSDM yang selama ini hanya dianggap sebagai kegiatan administrasi berkaitan dengan perekrutan tenaga pendidik yang dilakukan oleh panitia. Saat ini, MSDM berubah fungsi spesialisasi yang berdiri sendiri menjadi fungsi yang terintegrasi dengan seluruh fungsi lainnya di dalam organisasi, untuk bersama-sama mencapai sasaran yang sudah ditetapkan. Oleh karenanya MSDM memiliki kewajiban untuk memahami perubahan yang semakin kompleks yang selalu terjadi di lingkungan lembaga pendidikan sebagaimana mengantisipasi perubahan teknologi dan memahami dimensi internasional yang mulai memasuki lembaga akibat informasi yang berkembang pesat. Ada kecenderungan untuk mengakui pentingnya SDM dalam organisasi dan pemusatan perhatian pada kontribusi fungsi SDM bagi keberhasilan pencapaian tujuan strategi lembaga. Hal ini dapat dilakukan melalui rekrutmen tenaga pendidik yang selektif dengan mengintegrasikan pembuatan keputusan strategi dan fungsi maka semakin besar kesempatan untuk memperoleh keberhasilan.

Tujuan utama proses rekrutmen adalah mendapatkan tenaga pendidik yang tepat dalam suatu jabatan tertentu sehingga mampu bekerja secara optimal dan dapat bertahan di sekolah dalam jangka waktu yang lama. Pelaksanaan rekrutmen merupakan tugas yang sangat penting karena membutuhkan tanggung jawab yang besar dalam kemanfaatan sekolah. Sebagaimana pernyataan (Afif, Ulfatin, Kusmintardjo, \& Imron, 2017) profesionalisme seorang tenaga pendidik harus memiliki motivasi dan komitmen yang tinggi, meningkatkan kemampuan kompetensi dan performa, dan melaksanakan kegiatan pengajaran untuk pencapaian hasil yang lebih baik. Dengan demikian, melihat pentingnya kualitas tenaga pendidik dalam mencapai keberhasilan, lembaga sangat 
bergantung pada proses rekrutmen yang dilakukan oleh panitia pelaksana tersebut. Oleh karena itu, penulis tertarik untuk membahas tentang "Bagaimanakah Implementasi Rekrutmen Tenaga Pendidik di SMA 2 Darul Ulum Jombang".

Dalam rangka untuk mendapatkan tenaga pendidik yang berkualitas bergantung pada proses perekrutannya. Semakin baik proses perekrutannya maka semakin besar peluang untuk mendapatkan individu yang berkualitas sesuai dengan yang diharapkan oleh lembaga pendidikan. Rekrutmen merupakan kegiatan penerimaan tenaga pendidik yang bertujuan untuk memenuhi kebutuhan lembaga pendidikan baik jumlah maupun kualitasnya. (Handoko, 2011) menyatakan bahwa rekrutmen adalah proses pencarian calon karyawan yang mampu melamar sesuai dengan lowongan yang telah disediakan oleh lembaga tersebut. Menurut (Hobson, Ashby, McIntyre, \& Malderez, 2010) menjelaskan bahwa mekanisme penerimaan tenaga pendidik hendaknya mendapat perhatian yang serius karena pada tahap penerimaan ini dapat memilih dan menyeleksi para calon tenaga pendidik yang sesuai dengan kriteria yang diinginkan dan tujuan pendidikan yang dicapai. (Siagian, 2000) menjelaskan bahwa kesalahan dalam menyeleksi tenaga pendidik berakibat fatal bagi kelangsungan kegiatan pembelajaran yang berhubungan lansung dengan pencapaian tujuan yang diinginkan.

Berdasarkan pendapat diatas disimpulkan bahwa proses perekrutan tenaga pendidik memiliki peranan yang sangat penting, karena proses perekrutan yang baik dapat menghasilkan SDM yang berkualitas. (Wajdi, Rahayu, Ulfatin, Wiyono, \& Imron, 2018) bahwasanya profesionalisme tenaga pendidik mengacu pada inovasi tenaga pendidik, meliputi kepercayaan diri, tugas dan dampak pada outcome siswa; kecerdasan emosional, meliputi kemampuan mengekspresikan diri, regulasi diri, kesadaran diri, dan keterampilan sosial; kompetensi profesional tenaga pendidik, meliputi rencana pembelajaran, menerapkan proses pembelajaran dan penilaian. Pentingnya proses perekrutan yang berkualitas tersebut menyebabkan proses perekrutan tenaga pendidik menjadi salah satu perhatian negara-negara maju di dunia. Sebagai contoh menurut (Ostinelli, 2014), di Firlandia proses perekrutan tenaga pendidik memiliki regulasi sendiri dan diatur oleh perundang-undangan yang berlaku di negara tersebut. Selain fase masuk ke perencanaan, kualifikasi untuk mengajar di Firlandia juga tidak berdasarkan ujian, tetapi menggunakan metode penilaian lain, termasuk esai, tugas investigasi dan evaluasi kemampuan untuk mengetahui kemampuan mereka. (Ostinelli, 2014), menyatakan bahwa jenis perencanaan tenaga pendidik yang baik dapat mengarah pada munculnya profesionalitas tenaga pendidik yang sangat termotivasi dimana tingkat kesuksesan pendidikan juga meningkat.

Pengelolaan mulai dari perencanaan hingga pada tahap akhir, pada intinya diorientasikan untuk mencapai tujuan yang telah ditetapkan dalam organisasi dengan memenuhi syarat sebanyak mungkin. Selain itu, menurut (Handoko, 2011), pencarian dan perekrutan sejumlah karyawan yang berpotensi, diseleksi untuk memenuhi kebutuhan yang diinginkan oleh lembaga. Berdasarkan pendapat diatas dapat disimpulkan bahwa rekrutmen adalah suatu proses yang dihasilkan oleh kelompok para pelamar yang dapat memenuhi syrat untuk bekerja di lembaga pendidikan yang telah ditentukan. Rekrutmen juga mengikuti peroses seleksi yang bertujuan untuk mendapatkan kesesuaian kebutuhan tenaga pendidik yang dibutuhkan sesuai dengan ilmu yang dimiliki. Menurut (Bafadal, 2003) kegiatan rekrutmen SDM tenaga pendidik merupakan salah satu aktivitas manajemen yang berupaya mendapatkan tenaga pendidik yang berpotensi untuk menduduki posisi di sebuah lembaga pendidikan. Menurut (Supriyono, Imron, Arifin, \& Kusmintardjo, 2017) dalam hasil penelitiannya tenaga pendidik yang profesional mampu beradaptasi berbagai karakter siswa, memberikan pemahaman dalam pembelajaran, dapat mengembangkan kurikulum, dan dapat mengembangkan potensi siswa.

Menurut (Gomes \& Faustino, 1995), menyatakan bahwa rekrutmen dilakukan dalam suatu lembaga pendidikan memiliki beberapa alasan sehingga diadakan lowongan kerja. Adapun alasannya, meliputi (a) baru berdirinya suatu lembaga pendidikan; (b) adanya perluasan kegiatan dalam lembaga pendidikan; (c) penambahan pekerjaan dan kegiatan baru; (d) adanya tenaga pendidik yang pindah ke lembaga pendidikan lain; (e) adanya pekerja yang berhenti atau pensiun; (f) adanya tenaga pendidik yang meninggal dunia. Dari keenam alasan tersebut di atas suatu lembaga pendidikan segera melakukan perekrutan tenaga pendidik karena memiliki alasan-alasan tertentu sehingga terciptanya pekerjaan dan kegiatan baru di lembaga pendidikan.

(Bafadal, 2003) kegiatan pertama yang dilakukan untuk proses rekrutmen tenaga pendidik baru adalah melakukan persiapan dalam merekrut tenaga pendidik. Persiapan tersebut benar-benar matang sehingga adanya kegiatan rekrutmen tersebut sekolah dapat memperoleh tenaga pendidik yang baik sesuai dengan kebutuhan sekolah. Beberapa persiapan tenaga pendidik baru, meliputi (a) menentukan panitia; (b) pengkajian undang-undang yang telah ditentukan oleh pemerintah, peraturan yayasan yang berhubungan dengan peraturan penerimaan tenaga pendidik baru; (c) penetapan persyarat untuk melamar menjadi tenaag pendidik baru, (d) penetapan prosedur-prosedur pendaftaran tenaga pendidik baru (d) penetapan jadwal rekrutmen tenaga pendidik baru, (e) penyiapan fasilitas yang diperlukan dalam proses rekrutmen tenaga pendidik baru seperti media pengumuman penerimaan guru baru, format rekapitulasi pelamar, dan format rekapitulasi pelamar yang diterima; (f) menyiapkan ruang atau tempat memasukan lamaran tenaga pendidik baru; (g) menyiapkan bahan ujian seleksi, pedoman-pedoman pemeriksaan hasil ujian dan tempat ujian. Setelah persiapan selesai dilakukan, kegiatan selanjutnya adalah penyebaran pengumuman melalui media, seperti brosur, facebook, instagram, radio, majalah dan sebagainya. 
Pengumuman penerimaan tenaga pendidik yang baik yaitu berisi tentang waktu, tempat, persyaratan, dan prosedurprosedur mengajukan lamaran. Setelah pengumuman penerimaan lamaran tenaga pendidik baru telah disebarkan maka masyarakat mengetahui bahwa dalam jangka waktu tertentu, sebagaimana yang telah tercantum dalam pengumuman ada penerimaan tenaga pendidik baru di sekolah. Masyarakat yang berminat memasukkan lamarannya, panitia mulai menerima berkas lamaran yang sudah di tentukan. Kegiatan yang dilakukan panitia menurut (Isnaini, 2015), meliputi (a) melayani pelamar; (b) mengecek semua kelengkapan data lamaran; (c) mengecek isi yang terdapat dalam data lamaran.

Sebagai tenaga pendidik diharuskan untuk mengajukan lamaran pekerjaan di tempat yang telah ditentukan sesuai dngan rekrutmen masing-masing. Surat lamaran tersebut disertai dengan berbagai surat keterangan, contonya ijazah, transkrip nilai, akte kelahiran, surat keterangan warga Negara Indonesia, surat keterangan kesehatan dari dokter, dan surat keterangan kelakukan baik dari kepolisian. Setelah pendaftaran tenaga pendidik baru ditutup, kegiatan selanjutnya adalah seleksi atau penyaringan terhadap semua pelamar. Hal ini diperkuat oleh (Ramadoni, Kusmintardjo, \& Arifin, 2016) menyatakan bahwa keprofesionalan tenaga pendidik dapat diwujudkan dari kepala sekolah melalui penerapan kedisplinan, demokratis dan penerapan komunikasi yang baik.

(Bafadal, 2003) menyatakan untuk melakanakan rekrutmen tenaga pendidik perlu mengkaji ulang tentang berbagai persyaratan untuk menjadi tenaga pendidik yang baik dan benar. Sehingga tidak perlu ada kesalahan untuk mengangkat tenaga pendidik baru. Untuk melakukan peran dan melaksanakan tugas serta bertanggungjawab atas kinerjanya masing-masing, tenaga pendidik memerlukan syarat-syarat yang dibutukan dalam rekrutmen, meliputi (a) persyaratan teknis, (b) persyaratan administratif, (c) persyaratan fisik, dan (d) persyaratan psikis. Hal ini memiliki konotasi dalam menafsirkan masyarakat bahwa bagi tenaga pendidik yang memiliki ijazah dinilai mampu mengajar karena sudah mempunyai pengalaman dalam mengajar sebelumnya. Kemudian syarat-syarat yang lain adalah menguasai teknik mengajar, terampil mendesain program pengajaran serta memiliki motivasi dan cita-cita memajukan pendidikan/pengajaran yang berkaitan dengan kelompok persyaratan psikis, antara lain sehat rohani, dewasa dalam berpikir dan bertindak, mampu mengendalikan emosi, sabar, ramah dan sopan, memiliki jiwa kepemimpinan, konsekuen dan berani bertanggung jawab, berani berkorban serta memiliki jiwa pengabdian.

Sebagai tenaga pendidik juga dituntut untuk bersifat realistis, tetapi juga memiliki pandangan yang mendasar dan filosofis. Tenaga pendidik harus mematuhi aturan dan nilai yang berlaku serta memiliki semangat membangun. Penting juga bahwa tenaga pendidik mampu melakukan interaksi dan memberi motivasi dalam pembelajaran serta memiliki panggilan hati nurani menjadi tenaga pendidik untuk mengabdi demi anak didiknya. Persyaratan fisik, meliputi berbadan sehat, tidak memiliki cacat tubuh yang mengganggu pekerjaannya, dan tidak memiliki gejala-gejala penyakit yang menular. Dalam persyaratan fisik ini juga menyangkut kerapian dan kebersihan, termasuk bagaimana berpakaian sebab bagaimanapun juga tenaga pendidik senantiasa dilihat oleh anak didiknya.

Temuan penelitian manajemen pengembangan SDM Pondok Pesantren oleh (Haromain, 2014), meliputi (a) rekrutmen SDM dilakukan atas dasar kebutuhan SDM yang berkualitas, (b) melalui proses analisis kebutuhan pengembangan SDM, (c) umumnya dilakukan melalui penunjukan langsung oleh yayasan atas rekomendasi dari anggota kependidikan, (d) calon tenaga pendidik diambil dari alumni yang dianggap sudah memiliki kemampuan sehingga layak untuk ditugaskan sebagai tenaga pendidik, (e) calon tenaga pendidik yang berasal dari luar maka akan ditelusuri terlebih dahulu oleh panaitia untuk mengetahui aktivitas calon tersebut sehingga layak untuk mengikuti kegiatan belajar mengajar di sekolah tersebut, (f) untuk perekrutan umumnya tidak menggunakan pendekatan formal, tetapi lebih menekankan pada pendekatan spiritual kepada calon yang berkaitan tentang kedalaman ilmu agama salah satunya ditekankan pada membaca Al Quran, kepribadian, dan kesalehan dalam beragama.

\section{METODE}

Penelitian ini merupakan penelitian kualitatif yaitu untuk memahami fenomena yang dialami oleh subjek penelitian secara holistik dengan mendeskripsikan dalam bentuk kata-kata dan bahasa, pada suatu konteks khusus yang alamiah dengan memanfaatkan berbagai metode ilmiah, (Moleong, 2017). Penelitian ini dilakukan di SMA Darul Ulum 2 Jombang. Sumber data primer diperoleh dari hasil wawancara mendalam terhadap kepala sekolah sebagai informan kunci, wakil kepala sekolah sebagai informan utama, dan para guru sebagai informan pendukung. Data sekunder ini meliputi dokumen yang berkaitan dengan sekolah seperti data sistem perekrutan tenaga pendidik.

Teknik pengumpulan data dalam penelitian ini terdiri dari tiga tahap, yaitu (1) observasi, (2) dokumentasi, dan (3) wawancara mendalam. Analisis data dilakukan dengan menggunakan langkah-langkah yang dikemukakan oleh (Bungin, 2007), yaitu pengumpulan data, reduksi data, display data, verifikasi, dan pengesahan kesimpulan

\section{HASIL}

SMA Darul Ulum 2 Jombang didirikan pada tahun 1979 dibawah naungan Pondok Pesantren Darul 'Ulum (Rejoso), sejak dimulainya pembangunan sekolah didesain untuk menghadapi era globalisasi dan juga bekerja sama dengan Badan Pengkajian dan Penerapan Teknologi atau biasa disebut BPPT. Adapun Visi SMA 2 Darul Ulum Jombang yang Unggul dalam Iman dan Taqwa (Imtaq), Unggul dalam Ilmu Pengetahuan dan Teknologi (Iptek), dan Unggul dalam Berakhlakul Karimah. Misi SMA 2 Darul Ulum Jombang adalah membentuk siswa yang dapat membedakan antara baik dan buruk, memahami kandungan 
isi Alquran, melaksanakan sholat berjamaah, istighosah, tahlil, ESQ, perayaan hari besar Islam dan lain-lain, menyelenggarakan pendidikan secara terpadu antara sekolah, pondok, dan Cambridge International Examination (CIE), menyelenggarakan pembelajaran Full Days School, menumbuhkan semangat keunggulan secara intensif kepada seluruh warga sekolah, mendorong dan membantu siswa untuk mengenali potensi dirinya sehingga dapat dikembangkan secara optimal, mewujudkan peserta didik yang mampu berkompetisi di dalam negeri maupun di luar negeri, melaksanakan pembinaan akademik dan non akademik secara intensif, menfasilitasi kegiatan yang berbasis TIK serta saran pendukungnya, melaksanakan kegiatan pembinaan English Arabic seperti English Arabic morning, English Arabic day, English Arabic challenge, menerapkan sistem point, dan melaksanakan kegiatan bakti sosial dan green day.

Berdasarkan visi dan misi diatas yaitu bertujuan untuk membentuk siswa yang memiliki akhlak dan berkepribadian sesuai dengan nilai-nilai Islam untuk bekal hidup di dunia juga di tengah keluarga dan masyarakat. Sekolah SMA 2 Darul Ulum Jombang merupakan sekolah yang berusaha menghadirkan yang terbaik di era globalisasi. Sekolah SMA 2 Darul Ulum Jombang bercita-cita membentuk alumni yang berbangsa nasionalis, patriotis, beriman, bertaqwa, berkualitas dan sanggup menghadapi tantangan-tantangan pada zaman modern ini. Sekolah merupakan lembaga pendidikan formal yang diselenggarakannya kegiatan proses belajar dan memerlukan SDM yang berkualitas untuk keberhasilan sekolah tersebut.

Penyebaran pengumuman. Panitia rekrutmen yang telah dibentuk sekolah berkoordinasi dengan yayasan pondok pesantren untuk melakukan publikasi penerimaan tenaga pendidik baru di media media elektronik dan media massa. Seleksi administrasi merupakan tahapan seleksi awal sebelum masuk pada tahapan selanjutnya. Pada tahap ini, berkas pendaftaran dan kelengkapan prasyarat yang dimiliki oleh pelamar diteliti oleh panitia. Secara umum, terdapat dua jenis acuan yang digunakan, yaitu referensi pengalaman pendidikan atau pengalaman kerja pelamar dan referensi personal pelamar. Referensi pengalaman kerja dibutuhkan untuk mengetahui spesialisasi keahlian yang dimiliki pelamar, sedangkan referensi personal mencakup aspekaspek personal, seperti umur dan kelakuan baik pelamar.

Tes tulis merupakan serangkaian tes yang diberikan oleh SMA 2 Darul Ulum Jombang untuk mengukur kompetensi akademik dan psikologis yang dimiliki oleh pelamar. Tes tulis yang dilakukan di SMA 2 Darul Ulum Jombang, meliputi tes pengetahuan dasar keilmuan untuk mengukur kompetensi akademik yang dimiliki oleh calon tenaga pendidik serta tes potensial akademik untuk memantau calon tenaga pendidik memiliki etika serta motivasi yang baik. Tes wawancara dilakukan oleh yayasan sendiri. Pelamar dinyatakan lolos apabila sesuai dengan syarat dan kriteria yang diinginkan dari yayasan. Selanjutnya, sebagai bagian dari ujian, pelamar yang telah selesai melakukan tes tertulis dan wawancara diwajibkan untuk tidak membocorkan atau memberitahukan soal-soal ataupun pertanyaan-pertanyaan yang telah diujikan kepada siapapun dan ini dianggap sebagai salah satu bagian ujian dalam menerima amanah.

Tes micro teaching bertujuan untuk mengetahui kemampuan proses belajar mengajar yang dilakukan oleh SMA 2 Darul Ulum Jombang demi kelancaran dalam menentukan rekrutmen tersebut. Selain itu, tes Al-Qur'an bertujuan untuk mengetahui kompetensi dan kemampuan yang dimiliki oleh calon tenaga pendidik mengenai kemampuan baca dan tulis Al-Qur'an. Dalam proses seleksi, setiap tenaga pendidik pada semua mata pelajaran diharuskan untuk memiliki kemampuan ini. Kemampuan baca dan tulis Al-Qur'an merupakan kemampuan yang harus dimiliki oleh semua tenaga pendidik di SMA 2 Darul Ulum Jombang dan tidak terbatas pada tenaga pendidik di bidang ilmu agama saja. Penetapan syarat tersebut didasari alasan bahwa SMA 2 Darul Ulum Jombang merupakan lembaga pendidikan yang dinaungi oleh pondok pesantren dan mayoritas peserta didiknya juga berstatus sebagai santri.

\section{PEMBAHASAN}

Rekrutmen atau Penerimaan tenaga pendidik merupakan kegiatan untuk memenuhi kebutuhan tenaga lembaga pendidikan, baik jumlah maupun kualitasnya. Untuk kegiatan tersebut diperlukan kegiatan perekrutan. Menurut (Handoko, 2011) mengemukakan bahwa rekrutmen adalah proses pencarian dan pemikatan para calon karyawan (pelamar) yang mampu melamar sebagai karyawan. Menurut (Mangkunegara \& Anwar, 2002) rekrutmen adalah suatu proses atau tindakan yang dilakukan oleh perusahaan untuk mendapatkan tambahan pegawai melalui tahapan yang mencakup indentifikasi dan sumber-sumber penarikan pegawai, menentukan kebutuhan pegawai yang dibutuhkan lembaga pendidikan, proses seleksi, penempatan dan orientasi pegawai.

Rekrutmen tenaga pendidik merupakan hal yang sangat penting dilakukan berdasarkan dengan kebutuhan dan persyaratan yang ditentukan oleh sekolah agar mendapatkan SDM yang berkualitas dan professional. SMA 2 Darul Ulum Jombang memiliki strategi dan manajemen tersendiri yang digunakan dalam proses perekrutan tenaga pendidik.

\section{Proses Rekrutmen Tenaga Pendidik}

Proses rekrutmen untuk mendapatkan tenaga pendidik dan tepat untuk jabatan yang dibutuhkan sehingga mampu bekerja secara optimal dan dapat bertahan di sekolah dalam jangka waktu panjang. (Rahman, 2015) menjelaskan bahwa proses rekrutmen tenaga pendidik didalam suatu lembaga pendidikan adalah usaha mencari tenaga pendidik yang memiliki kompetensi, kecakapan dan ahli dalam mendidik dan mengajar sesuai bidangnya. Di samping itu, sangat penting dimiliki oleh seorang tenaga pendidik 
adalah sifat jujur serta memiliki jasmani yang sehat sehingga dapat menjalankan tugasnya dalam mencerdaskan anak bangsa. (Kurnia \& Santoso, 2018) juga menyatakan bahwa rekrutmen pada dasarnya adalah usaha untuk mengisi jabatan atau pekerjaan yang kosong sesuai dengan lingkungan suatu organisasi atau lembaga. Oleh karena itu, terdapat dua sumber tenaga kerja luar (eksternal) atau dari dalam (internal) organisasi.

Proses rekrutmen tenaga pendidik baru dilakukan secara selektif karena rekrutmen sangat penting untuk masa depan peserta didik, melalui proses rekrutmen, sekolah mendapatkan SDM yang berkualitas. Berdasarkan hasil wawancara dan observasi yang dilakukan, dapat dianalisis bahwa implementasi rekrutmen tenaga pendidik di sekolah SMA 2 Darul Ulum Jombang untuk mendapatkan tenaga pendidik yang profesional juga memiliki kualifikasi yang baik. Rekrutmen tenaga pendidik baru tidak diadakan tiap tahun karena sesuai dengan kebutuhan sekolah. Jika ada posisi yang kosong maka diadakan perekrutan tenaga pendidik baru untuk mengisi posisi jabatan yang sesuai keahliannya. Sebelumnya kegiatan tersebut memerlukan persiapanpersiapan yang matang dalam memilih tenaga pendidik. Dengan adanya persiapan ini pihak yayasan melakukan pembentukan panitia rekrutmen tenaga pendidik baru, agar mempermudah program kerja dalam memproses perekrutan tenaga pendidik sehingga dapat tersusun secara sistematis yang dapat berjalan sesuai yang diinginkan. Tenaga pendidik di sekolah ini tidak diikutsertakan dalam mempersiapkan bahan untuk penyeleksian calon tenaga pendidik baru karena pihak yayasan melakukan penyeleksi terlebih dahulu, lalu diserahkan kepada kepala sekolah, dan kepala sekolah menyerahkan tugas sepenuhnya kepada bagian personalia dalam proses rekrutmen tenaga pendidik baru. Adapun personalia yang terlibat dalam perekrutan tenaga pendidik baru, meliputi wakil kepala sekolah, bidang kurikulum, bidang kesiswaan, psikologi, dan bimbingan konseling. Sementara itu, tenaga pendidik hanya sekedar mendapatkan informasi bahwa diadakannya perekrutan tenaga pendidik baru karena tugas mereka lebih difokuskan pada kegiatan belajar mengajar agar kegiatan mereka tidak tercampur dengan kegiatan lainnya.

Pihak sekolah dalam melaksanakan proses rekrutmen tenaga pendidik baru yaitu melakukan pengkajian berbagai Peraturan Pemerintah, namun Peraturan Pemerintah tersebut hanya menjadi acuan dalam membantu kegiatan ini karena pihak yayasan sudah memiliki pedoman tersendiri yang berkenaan dengan peraturan penerimaan tenaga pendidik baru. Selain itu, pihak sekolah juga menetapkan prosedur pendaftaran tenaga pendidik baru karena melalui prosedur pendaftaran tersebut dapat mempermudah para pelamar sebagai syarat untuk calon tenaga pendidik baru agar dapat lolos seleksi administrasi, dan data para pelamar tersebut dimasukkan ke ruang personalia agar tidak tercampur dengan berkas lainnya. Cara masyarakat untuk memperoleh informasi tentang diadakannya perekrutan tenaga pendidik baru di sekolah ini yaitu langsung datang ke sekolah dan menyerahkan berkas lamaran. Begitu pengumuman penerimaan tenaga pendidik baru telah disebarkan tentu masyarakat mengetahui bahwa dalam jangka waktu tertentu, sebagaimana tercantum dalam pengumuman, ada penerimaan tenaga pendidik baru di sekolah. Mengetahui ada penerimaan tenaga pendidik baru, masyarakat yang berminat menaruh lamarannya. Pihak dari panitiapun mulai menerima dan menyeleksi lamaran tersebut.

\section{Kegiatan Rekrutmen Tenaga Pendidik}

Kegiatan yang dilakukan panitia adalah mengecek semua kelengkapan yang harus disertakan dengan data lamaran apakah dapat menunjang pelamar lolos dari seleksi berkas. Kemudian pihak sekolah merekap semua berkas pelamar dalam format rekapitulasi, tujuannya agar mempermudah pihak sekolah untuk mengetahui para pelamar yang masuk kemudian lanjut untuk diseleksi. Syarat-syarat seleksi ini dibuat sendiri oleh sekolah (otonomi sekolah) bukan pemerintah sehingga pihak sekolah lebih berkuasa dalam menentukan prosedurnya. (Ratnasari, 2013) menyatakan bahwa dalam melakukan pendaftaran untuk para calon tenaga pendidik harus memiliki beberapa persyaratan yang telah dibutukan oleh lembaga pendidikan yang membuat lowongan.

Tes seleksi biasa diberikan kepada calon tenaga pendidik baru di sekolah dengan psikotes, kesehatan, micro teaching, wawancara, tes baca Al-Quran salah satu kewajiban alasannya sekolah ini dinaungi oleh yayasan pondok pesantren. Membuat rencana pembelajaran jika tenaga pendidik tersebut sudah diterima oleh sekolah maka tenaga pendidik mamapu berbahasa Inggris, berbahasa Arab serta bahasa lainnya. Disamping itu, pihak sekolah memiliki standar seleksi yang merupakan penting untuk dilaksanakan oleh setiap lembaga pendidikan dengan melakukan seleksi yang selektif sehingga menghasilkan para tenaga pendidik yang berkualitas.

Kualifikasi yang diberikan kepada calon tenaga pendidik baru agar dapat lolos dalam seleksi administrasi yaitu minimal telah menyelesaikan program SI, pengalaman mengajar, prestasi belajar mengajar, uji sertifkasi guru, IP (3.00), lancar berbicara bahasa Inggris. Dengan melakukan penyaringan seleksi administrasi maka posisi jabatan yang lowong pun dapat terisi sesuai yang diinginkan. Pihak sekolah dalam merekrut tenaga pendidik baru melakukan persyaratan teknis dalam mengajar yaitu dengan tes micro teaching yang dilakukan oleh calon tenaga pendidik baru sebagai salah satu syarat yang diajukan oleh pihak sekolah yang bertujuan untuk mengetahui bagaimana mengajar mereka sehingga didapatkan tenaga pendidik yang professional dalam mendidik peserta didik. Selain itu, pihak dari sekolahpun dapat mengetahui kepribadian tenaga pendidik yang utuh dan berkualitas karena dari sinilah muncul tanggungjawab profesional sekaligus menjadi inti kekuatan bagi semua orang yang memiliki profesi seorang tenaga pendidik dan juga kesiapan untuk selalu mengembangkan diri. 
Kompetensi kepribadian juga ikut berperan sebagai tenaga pendidik memerlukan kepribadian yang unik, kepribadian tenaga pendidik seperti kemampuan kepribadian yang berwibawa, dewasa, stabil, dan arif juga menjadi teladan bagi peserta didiknya serta memiliki akhlak yang mulia. (Murnawati, 2014) menyatakan bahwa dengan tenaga pendidik yang berusia produktif, tenaga pendidik memiliki pengalaman dalam bekerja yang tinggi. Para tenaga pendidik yang lebih tua terdapat kualitas positif terhadap pekerjaan mereka khususnya pengalaman yang dimiliki, penilaian, etika kerja yang kuat, serta memiliki komitmen terhadap kualitas. Dengan psikotes, pihak sekolah dapat mengetahui bagaimana tingkat motivasi dan komitmen mereka terhadap sekolah. Selain itu, dengan tes kesehatan pihak sekolah mendapatkan calon tenaga pendidik baru yang sehat jasmani dan rohaninya.

Dari semua tahap kegiatan proses rekrutmen tenaga pendidik baru yang sudah dilaksanakan di sekolah SMA 2 Darul Ulum Jombang tentunya tidak terlepas dari kontribusi kepala sekolah dan juga kepala yayasan, dalam hal ini kontribusinya kepala sekolah dan kepala yayasan sudah cukup maksimal yaitu dengan mengatur tentang prosedur-prosedur yang telah ditetapkan dan menyerahkan proses kegiatan ini sepenuhnya kepada bagian personalia sehingga kegiatan dapat berjalan dengan baik karena sebelumnya sudah tersusun secara sistematis oleh pihak sekolah sangat selektif dalam memilih calon tenaga pendidik baru yang akhirnya dapat menghasilkan SDM tenaga pendidik yang berkualitas dan profesional sesuai dengan bidangnya dan dapat memberi dampak peningkatan mutu pendidikan di sekolah tersebut. Diperkuat oleh (Rahman, 2015) bahwa mutu sebuah kelulusan (outcome) adalah kualitas peserta didik dapat melanjutkan pendidikan ke jenjang yang lebih tinggi dan jika dapat melanjutkan pendidikannya, maka dalam dunia kerja dapat diterima dengan baik, mandiri, serta diterima dengan baik dalam kehidupan bermasyarakat pula.

\section{SIMPULAN}

Berdasarkan hasil pembahasan di atas maka dapat disimpulkan bahwa (a) kepala sekolah dan kepala yayasan sudah melakukan semaksimal mungkin dalam memberikan kontribusinya terhadap proses rekrutmen tenaga pendidik. Hal ini dilihat dari pemberian wewenang sepenuhnya kepada pihak panitia untuk melakukan proses rekrutmen tenaga pendidik baru. Tentunya sudah sesuai dengan prosedur yang telah ditetapkan oleh pihak sekolah, (b) proses rekrutmen yang dilaksanakan oleh pihak sekolah sudah cukup efektif dan efisien. Hal ini dapat dilihat dari kegiatan proses rekrutmen tenaga pendidik baru yang dilakukan oleh pihak sekolah secara selektif dan sistematis sehingga menghasilkan SDM yang berkualitas serta memiliki kemampuan yang sesuai dengan tujuan pendidikan nasional, dan (c) dalam proses rekrutmen tenaga pendidik baru di sekolah ini, tenaga pendidik tidak dilibatkan karena kepala sekolah menyerahkan tugas sepenuhnya kepada bagian personalia saja, dan para tenaga pendidik di sekolah hanya sekedar mendapatkan informasi saja tentang diadakannya kegiatan proses rekrutmen tenaga pendidik baru karena tugas mereka lebih difokuskan kepada kegiatan belajar mengajar agar kegiatan mereka tidak terganggu dengan kegiatan lainnya.

Saran diatas ditujukan kepada (a) kepala sekolah, hasil penelitian ini nantinya dapat dijadikan sebagai masukan bagi kepala sekolah dalam manajemen sumber daya tenaga pendidik yang ada di sekolah agar dapat berperan dan bertugas secara maksimal, (b) pihak personalia, dalam melaksanakan proses rekrutmen harus selektif dan tidak terpengaruh oleh tekanan-tekanan dari luar atau hal apapun yang berdampak kecurangan, dan (c) bagi peneliti lanjutan memberikan informasi dan pengetahuan sebagai referensi terkait dengan MSDM yang sesuai dengan tujuan pendidikan.

\section{DAFTAR RUJUKAN}

Afif, Z. N. M., Ulfatin, N., Kusmintardjo., \& Imron, A. (2017). Pedagogical Competence Improvement of Teachers Through a Neuro Linguistic Programming (NLP) in Indonesia. In International Conference on Education (ICE2) 2018: Education and Innovation in Science in the Digital Era, 991-1007.

Bafadal, I. (2003). Peningkatan Profesionalisme Guru Sekolah Dasar Dalam Kerangka Manajemen Peningkatan Mutu Berbasis Sekolah. Jakarta: Bumi Aksara.

Bungin, B. (2007). Analisis Data Penelitian Kualitatif. PT Raja Grafindo Persada.

Gomes, G., \& Faustino, C. (1995). Manajemen Sumber Daya Manusia. Yogyakarta: Andi Offset.

Handoko. (2011). Manajemen Personalia dan Sumber Daya Manusia. Yogyakarta: BPFE.

Haromain. (2014). Manajemen Pengembangan Sumber Daya Manusia (SDM) Pondok Pesantren. Jurnal Pendidikan Humaniora, 1(2), 136-149.

Hobson, A. J., Ashby, P., McIntyre, J., \& Malderez, A. (2010). International Approaches to Teacher Selection and Recruitment (No. 47).

Isnaini, R. L. (2015). Implementasi Rekrutmen Guru di SD Ta'mirul Islam Surakarta (Kajian Manajemen Sumber Daya Manusia di SD Islam). Jurnal Pendidikan Agama Islam UIN Sunan Kalijaga, 12(1), 109-120.

Kurnia, R. M., \& Santoso, M. B. (2018). Proses Rekruitmen dan Seleksi Pekerja K3L Unpad. Focus: Jurnal Pekerjaan Sosial, 1(2), 108-118.

Listanti, A. N., \& Nurhikmahyanti, D. (2014). Rekrutmen dan Seleksi Guru di SMA Al-Islan Krian. Jurnal Inspirasi Manajemen Pendidikan, 4(4), 98-107. 
Mangkunegara., \& Anwar, P. (2002). Manajemen Sumber Daya Manusia. Bandung: PT. Remaja Rosda Karya.

Moleong, J. (2017). Metodologi Penelitian Kualitatif. Bandung: Remaja Rosdakarya.

Murnawati. (2014). Analisis Rekrutmen Tenaga Pendidik pada SD Kalam Kudus Pekanbaru. Jurnal Ilmiah Ekonomi dan Bisnis, $11(2), 521-532$.

Ostinelli, G. (2014). Teacher Education in Italy, Germany, England, Sweden, and Finland. European Journal of Education, 44(2), 291-308.

Rahman, K. A. (2015). Rekrutmen Tenaga Pendidik dalam Peningkatan Mutu Madrasah Aliyah Negeri Insan Cendekia Jambi. Nadwa, 9(1), 23-38.

Ramadoni, W., Kusmintardjo., \& Arifin, I. (2016). Kepemimpinan Kepala Sekolah dalam Upaya Peningkatan Kinerja Guru. Jurnal Pendidikan: Teori, Penelitian, dan Pengembangan, 1(8), 1500-1504.

Ratnasari, D. (2013). Studi tentang Proses Rekrutmen Tenaga Kerja Perlindungan Masyarakat (Linmas) di Badan Kesatuan Bangsa, Politik dan Perlindungan Masyarakat Kabupaten Malinau. Jurnal Pemerintahan Integratif, 1(1), 75-90.

Siagian, S. P. (2000). Manajemen Sumber Daya Manusia. Jakarta: Bumi Aksara.

Supriyono., Imron, A., Arifin, I., \& Kusmintardjo. (2017). The Situational Behavior Orientation of Instructional Supervision: A Multisite Study. In 2nd International Conference on Educational Management and Administration (CoEMA 2017). Atlantis Press.

Wajdi, M. B. N., Rahayu, S., Ulfatin, N., Wiyono, B. B., \& Imron, A. (2018). The Professional Competency Teachers Mediate the Influence of Teacher Innovation and Emotional Intelligence on School Security. Journal of Social Studies Education Research, 9(2), 210-227. 